\title{
Examining the role of arginase in air pollution- induced exacerbation of asthma
}

\author{
Michelle L North ${ }^{1,2,3,4^{*}}$, Hajera Amatullah ${ }^{3,4,5}$, Nivedita Khanna ${ }^{2,3,4}$, Bruce Urch ${ }^{1,4}$, Mary Speck ${ }^{4}$, \\ Hartmut Grasemann ${ }^{1,6}$, Frances Silverman ${ }^{1,2,3,4,5}$, Jeremy A Scott ${ }^{1,2,3,4,5}$ \\ From AllerGen NCE Inc.'s Fifth Annual Research Conference: Innovation from Cell to Society \\ Québec City, QC, Canada. 7-9 February 2010
}

\section{Background}

The arginase isozymes (arginase 1 and 2), convert Larginine into L-ornithine and urea, and thus compete with the nitric oxide synthase isozymes for substrate. We have previously shown that arginase 1 expression is upregulated in human asthma and plays a functional role in airways hyperresponsiveness (AHR) in an animal model of allergic airways inflammation. Ambient particles and ozone are major constituents of urban air pollution and contribute to asthma exacerbations. However, the mechanisms underlying the exacerbation of allergic airways disease by air pollution remain to be elucidated. There is evidence that arginase expression is augmented in cigarette smoking asthmatics. We tested the hypothesis that arginase is involved in the exacerbation of respiratory symptoms in response to air pollution in animal models of allergic airways inflammation.

\section{Methods}

We used sub-acute (16-day) and chronic (12-week) murine models of ovalbumin (OVA)-induced allergic airways inflammation as models of asthma. All mice were sensitized to OVA, and then randomized to aerosol challenge with PBS (control; OVA/PBS) or OVA (allergic airways inflammation; OVA/OVA). Twentyfour hours after the final OVA or PBS challenge, mice underwent a combined exposure to concentrated ambient fine particles plus ozone $\left(\mathrm{CAP}+\mathrm{O}_{3}\right)$, or filtered air. Following exposure, mice were treated with either the arginase inhibitor $S$-boronoethyl l-cysteine (BEC; $40 \mu \mathrm{g} /$ g b.w.), or vehicle (PBS), by direct nebulization into the airways. After determination of the airways responsiveness to methacholine using the flexiVent, tissues were

${ }^{1}$ Institutes of Medical Sciences, Faculty of Medicine, University of Toronto, Toronto, Canada

Full list of author information is available at the end of the article harvested for Western blotting, activity testing and immunohistochemistry.

\section{Results}

Exposure to $\mathrm{CAP}+\mathrm{O}_{3}$ augmented the AHR in the OVA/ OVA mice with no significant effect on the OVA/PBS controls in both the sub-acute and chronic models. Expression of arginase 1 and total arginase activity were significantly augmented in OVA/OVA mice exposed to $\mathrm{CAP}+\mathrm{O}_{3}$, compared to filtered air. Immunohistochemistry revealed that arginase 1 expression was specifically up-regulated in the peribronchiolar region following $\mathrm{CAP}+\mathrm{O}_{3}$ exposure in OVA/OVA mice. Treatment with BEC significantly reduced the pollution-induced AHR in $\mathrm{CAP}+\mathrm{O}_{3}$-exposed OVA/OVA mice in both the subacute and chronic murine models to control levels.

\section{Conclusions}

This study demonstrates that arginase 1 is up-regulated following environmental exposures in murine models of allergic airways inflammation. Attenuation of airways hyperresponsiveness by arginase inhibition suggests that this pathway is a promising candidate for future therapies to prevent or treat air pollution-induced exacerbation of allergic symptoms.

\section{Acknowledgements}

This study was supported by AllerGen NCE, National Sanitarium Association, St. Michael's Hospital Research Centre. MN is a recipient of CIHR and OTS Doctoral Awards.

\section{Author details}

${ }^{1}$ Institutes of Medical Sciences, Faculty of Medicine, University of Toronto, Toronto, Canada. ${ }^{2}$ Divisions of Occupational and Respiratory Medicine, University of Toronto, Toronto, Canada. ${ }^{3}$ Keenan Research Centre in the Li Ka Shing Knowledge Institute, St. Michael's Hospital, Toronto, Canada. ${ }^{4}$ The Gage Occupational and Environmental Health Unit, St. Michael's Hospital, Toronto, Canada. ${ }^{5}$ Occupational and Environmental Health Program, Dalla 
Published: 26 November 2010

doi:10.1186/1710-1492-6-S3-P5

Cite this article as: North et al: Examining the role of arginase in air pollution-induced exacerbation of asthma. Allergy, Asthma \& Clinical Immunology 2010 6(Suppl 3):P5.

Submit your next manuscript to BioMed Central and take full advantage of:

- Convenient online submission

- Thorough peer review

- No space constraints or color figure charges

- Immediate publication on acceptance

- Inclusion in PubMed, CAS, Scopus and Google Scholar

- Research which is freely available for redistribution

Submit your manuscript at www.biomedcentral.com/submit 